Sokolov, S. Ia. (1957). Sovremennoe sostoianie teorii akklimatizatsii i introduktsii rastenii. Introduktsiia rastenii i zelenoestroitel'stvo. Ser. 6. Vyp. 5. S. 34-42. (in Russian).

St-Pierre R. G. (2005). Growing saskatoons - A manual for orchardists. Saskatoon: University of Saskatchewan. 338 p.

Strela, T. E. (1970). Biologicheskie osobennosti vidov roda irga (Amelanchier Medic.) i perspektivy ikh ispol'zovaniia: avtoref. diss. Na soiskanie nauch. stepenikand. s.-kh. nauk: 06.536 «Plodovodstvo». Kiev. 23 c. (in Russian).

Talent, N. \& Dickinson, T. A. (2007). Apomixis and hybridization in Rosaceae subtribe Pyrinae Dumort.: a new tool promises new insights. Regnum Vegetabile. Vol. 147. P. 301-316.

Wani, S. H., Kumar, V., Shriram, V. \& Sah, S. K. (2016). Phytohormones and their metabolic engineering for abiotic stress tolerance in crop plants. The Crop Journal. Vol. 4. № 3. P. 162-176. DOI: 10.1016/j. cj.2016.01.010

Yang, F. \& Baoguo Du. (2017). In vitro proliferation of Saskatoon berry (Amelanchier alnifolia Nutt) is affected by plant growth regulators and their concentrations but less by carbon source. Indian Journal of Biotechnology. Vol 16. № 4. P. 648-654.

\title{
Створення колекційно-експозиційних ділянок монокультури роду Rhododendron L. в ландшафті кварталу № 1 Національного дендрологічного парку «Софіївка» НАН України
}

\author{
Людмила В. Вегера \\ Наџіональний дендрологічний парк «Софіївка» НАН України, м. Умань, Черкаської обл.., Україна, \\ e-mail: lyudmila1vegera@gmail.com \\ ORCID ID0000-0003-2512-2664
}

Реферат.

Meта роботи - розкрити наступні питання: виявити доџільність відновлення інтродукџї роду Rhododendron у Наџіональному дендрологічному парку «Софіївка»; висвітлити причини недостатнього впровадження рододендронів в озеленення дендропарку та в інших установах Україн; навести основні обгрунтування шодо розмішення колекџійно-експозиџійних ділянок монокультури роду в ландшафті кварталу № 1 (Адміністративна територія). Џе спонукало до проведення наших досліджень та побудови план-схеми колекџійно-експозиџійних ділянок Rhododendron з таксономічним складом кущів на території кварталу № 1. Методи. На основі пошуку літературних даних та узагальнення звітних документів вивчали передумови для відновлення насаджень роду Rhododendron, етапи створення, таксономічний склад колекџійно-експозиџійних ділянок рододендронів в ландшафті території адміністративної частини (квартал № 1) дендрологічного парку «Софіївка». Результати. Перші згадки шодо наявності представників роду Rhododendron в озелененні дендрологічного парку «Софіївка» стосуються періоду правління Потоџьких. Основними причинами недостатнього впровадження рододендронів в озеленення дендропарку та інші ботанічні установи України було недостатнє вітчизняне виробниџтво садивного матеріалу та недостатні знання фахівџів-озеленювачів з питань технологї вироџування та створення стійких високодекоративних насаджень рододендронів. Розмішення колекџійно-експозиџійних ділянок в ландшафті кварталу № 1 дендрологічного парку «Софіївка» передбачало вирішення декількох питань: благоустрій і розширення асортименту гарноквітучих кушів 
в озелененні адміністративної території; полегшення догляду за насадженнями рододендронів, зокрема можливості вчасного поливу і зрошення рослин у спекотні дні сезону. Висновки. Створення ділянок та розмішення на них таксонів рододендронів грунтувалось на біолого-екологічних особливостях їх росту і розвитку. Наведено план-схему кварталу № 1 (Адміністративна територія парку) з розташуванням 11-ти колекџійно-експозијійних ділянок Rhododendron з таксономічним складом рослин, що слугуватиме проведенню локального моніторингу ділянок Rhododendron та їх видового складу у даному кварталі.

Ключові слова: насадження рододендронів, адміністративна територія, передумови, план-схема, таксономічний склад.

\title{
Creation of Collection and Exposition Plots of the Rhododendron L. Genus Monoculture in Landscape Section № 1 of the National Dendrological Park «Sofiyivka» of NAS of Ukraine
}

\author{
Liudmyla V. Vehera \\ National Dendrological Park «Sofiyivka» of NAS of Ukraine, Uman, Cherkasy region, Ukraine, e-mail: lyudmila1vegera@gmail.com \\ ORCID ID0000-0003-2512-2664
}

\begin{abstract}
.
Aims. The aim of the article is the following: to ascertain the expediency of the Rhododendron genus introduction renewal in the National Dendrological Park «Sofiyivka»; to find out the reasons for the insufficient introduction of rhododendrons into the landscaping of the Dendrological Park and other institutions in Ukraine; to ground the collection and exposition plots of the genus in the Section № 1 (administrative territory). The above mentioned led to the research conducting and to the drawing up a plan chart of the Rhododendron collection and exposition plots on the territory of the Section № 1 with taxonomic composition of the bushes. Methods. Based on literary data and generalization of reporting documents, the author studied the preconditions for the restoration of Rhododendron genus plantings, stages of its creation, the taxonomic composition of the collection and exposition plots of the rhododendrons in the landscape of the Administrative Territory (Section № 1) of the Dendrological Park «Sofiyivka». Results. The first mentions of presence the Rhododendron genus representatives in the landscaping of the Dendrological Park «Sofiyivka» refer to the period of the Potockis' rule. The main reasons for the insufficient introduction of the rhododendrons into the landscaping of the Dendrological Park and other botanical institutions in Ukraine are the following: insufficient domestic production of planting stock; landscapers' deficient knowledge on the issues of growing technology and creating the resistant and highly decorative plantings of the rhododendrons. The situating of the collection and exposition plots in the Section № 1 landscape of the Dendrological Park «Sofiyivka» provides for solving the following tasks: improvement and expansion of well-flowering bushes assortment in the greening of the administrative territory; facilitating to the rhododendrons plantings care, in particular, timely watering the plants on hot days of the season. Conclusions. The creation of the plots and placement the rhododendron taxons over them had been grounded on biological and ecological peculiarities of its growth and development. The author presents the plan chart of the Section № 1 (administrative territory of the park) with the placement of 11 collection and exposition plots of the Rhododendron with the taxonomic composition of the plants. It helps in carrying out a local monitoring of the plots with Rhododendron and their taxonomic composition in this section.
\end{abstract}

Key words: rhododendron plantings, administrative territory, preconditions, plan chart, taxonomic composition.

Вступ/Introduction. 3 кожним роком все частіше в ландшафтах дендрологічних парків і ботанічних садів можна побачити представників одного з найчисленніших родів родини Ericaceae DC - Rhododendron L. За літературними даними у природних умовах їх описано понад 1200 дикорослих видів та різновидів (Kondratovich, 1981). Нині в ботанічних установах на теренах України випробувано багато видів, форм та сортів рододендронів відкритого грунту різного географічного походження, з яких лише 2 види (Rh. luteum Sweet, Rh. kotschyi Simonk.) ростуть в природних грунтово-кліматичних умовах 
України (Vehera, 2011). Серед ботанічних садів і парків основним місџем інтродукџї роду Rhododendron в Україні є ботанічний сад ім. О.В. Фоміна Київського наџіонального університету ім. Тараса Шевченка, де ростуть понад 160 таксонів роду (Zarubenko, 2006). Названий ботанічний сад став осередком поширення саджанџів та сіянџів видових рододендронів в північному та центральному регіонах України. Осередком розповсюдження видових рододендронів в західному регіоні України є ботанічний сад Львівського наџіонального університету ім. І. Франка, тут росте понад 96 таксонів (Tymchyshyn, 2003). Впродовж останнього десятиріччя надзвичайно велика робота з інтродукџії представників роду Rhododendron проведена Національним ботанічним садом ім. М. М. Гришка (росте близько 90 таксонів). Створений тут і відкритий у 2012 роџі «Вересовий сад», є прикладом створення вересових садів на теренах України та сприяє популяризаџії рододендронів, зокрема видових (Shumyk, 2012).

У Наџіональному дендрологічному парку «Софіївк» НАН України культивування рододендронів є одним із шляхів збагачення генофонду дендрофлори південної частини Правобережного Лісостепу Украіни та власне дендропарку гарно квітучими кущами (Vehera, 2000).

Мета нашої роботи - розкрити наступні питання: виявити доџільність відновлення інтродукџї роду Rhododendron у Наџіональному дендрологічному парку «Софіївка» НАН України; висвітлити причини недостатнього впровадження рододендронів в озеленення дендропарку; навести основні обгрунтування шодо розмішення колекџійно-експозиџійних ділянок монокультури роду в ландшафті кварталу № 1 (Адміністративна територія). Все џе спонукало до проведення наших досліджень та побудови плансхеми колекџійно-експозиџійних ділянок Rhododendron з таксономічним складом кушів на території кварталу № 1.

Матеріали і методи/Materials and Methodology. На основі пошуку літературних даних та узагальнення звітних документів вивчали передумови для відновлення насаджень роду Rhododendron та етапи створення, таксономічний склад колекџійно-експозиџійних ділянок рододендронів в ландшафті території адміністративної частини (квартал №1) Наџіонального дендрологічного парку «Софіївка» $\mathrm{HAH}$ України.
Результати та обговорення/Results and Discussion. Відомості шодо наявності перших представників роду Rhododendron в озелененні дендрологічного парку «Софіївка» стосуються періоду правління Потоџьких (Kosenko et al., 1996). 3 архівних матеріалів відомо, шо Azalea pontica L. входила до переліку рослин, які використовувались для озеленення партеру. Наступна інформаџія про культивування рододендронів у дендрологічному парку «Софіївка» датується 1975 роком (усне повідомлення), коли з Алтайської дослідної станџї було доставлено кілька саджанџів Rh. ledebourii Pojark. і один саджанеџь вічнозеленого рододендрона гібридного походження, який для кліматичних умов нашого регіону має низьку зимостійкість, на шо вказували часті обмерзання куша (Vegera, 1995). На той час існувало, на нашу думку, кілька причин недостатнього впровадження рододендронів в озеленення дендропарку та інші ботанічні установи України. Одна з них - недостатнє виробниџтво садивного матеріалу, оскільки існуючі в Україні розсадники вирощуванням саджанџів рододендронів не займалися, а наявні у садових џентрах сортові саджанџі рододендронів були зарубіжного походження, досить дороговартісними та малопристосованими до кліматичних умов нашого регіону. Другою важливою причиною, як підтвердив досвід культивування џих рослин у дендрологічному парку «Софіївка», були недостатні знання фахівців-озеленювачів та садівників-аматорів з питань технології вирошування та створення стійких високо декоративних насаджень рододендронів (Zarubenko, 2006; Vehera, 2006). Наразі џю прогалину заповнено дисертаџійними дослідженнями, проведеними на базі ботанічних садів і дендрологічних парків у різних регіонах України з культурою роду Rhododendron. Також видано монографічні роботи та практичні рекомендаџії, які допомагають орієнтуватися у багатьох складних питаннях шодо створення насаджень та догляду за ними (Tymchyshyn, 2003; 2003; Vanzar, 1998; Vehera, 2000; 2006; Zarubenko et al., 2004; Zarubenko, 2006;).

Власне інтродукџї роду Rhododendron у Наџіональному дендрологічному парку «Софіївка» приділено значну увагу на початку 1990-х років. У џей період з метою з'ясування біолого-екологічних особливостей рододендронів в умовах Правобережного Лісостепу України було залучено для досліджень з ботанічного саду ім. О.В. Фоміна та Џентрального ботанічного саду НАН Білорусі близько 20 таксонів 
роду, з яких з часом було отримано власний садивний матеріал (Vehera, 1995; 2000; 2002).

На прикладі багаторічного досвіду культивування рододендронів у ботанічних садах України, зокрема ботанічному саду ім. І. Франка Аьвівського наџіонального університету (Tymchyshyn, 2003; 2003), ім. В. О. Фоміна Київського наџіонального університету (Zarubenko, 1989; 1996; 2000; 2001; 2006), багато видів, різновидів, форм і сортів можна успішно культивувати в умовах парку та за їх участю створити затишні та привабливі куточки відпочинку. Отож, нами було враховано досвід та доробки фахівџів названих установ і в наступні кілька десятиріч колекџія роду Rhododendron у Наџіональному дендрологічному парку «Софіївка» суттєво поповнилась і нині нараховує 62 таксони.

На жаль, у 1990-х роках спроби розмішення кількох ділянок з насадженнями рододендронів у новій частині паркової зони (квартали № 4, 5) були невиправданими. Окрім антропогенного навантаження рослини потерпали також від водоплавних птахів (лебедів), які общипували та поїдали однорічні прирости. Крім џього, виникла проблема з вчасним поливом рослин.

Коли після невдалого досвіду створення насаджень рододендронів у новій західній частині парку виникла необхідність вибрати інші місџя для садіння, то було прийнято рішення переважну кількість ділянок з рододендронами розмістити в ландшафті території адміністративної частини (квартал № 1). Такий вибір передбачав вирішення декількох питань. По-перше: благоустрій і озеленення џієї частини парку розширеним асортиментом гарно квітучих кущів, оскільки види роду Rhododendron $\epsilon$ џінними рослинами, які в зеленому будівниџтві часто використовуються для створення яскравих акџентів у декоративних композиџіях (Aleksandrova, 2000). Серед деревних рослин, що вже росли на зазначеній території (Ginkgo biloba L., види Malus L., Buxus sempervirens L, Viburnum lantana 'Aurea', види і форми Picea L., форми Thuja occidentalis L., Aesculus hippocastanum L., Syringa vulgaris L., Deutzia scabra Thunb. та ін.), рододендрони можна виокремити як найефектнішими, шо навесні вражають бруньками, шо розпускаються, незвичним яскравим џвітінням, розмірами та формою суџвіть, восени - золотистими, червоними, багряними кольорами листків, а взимку - вічнозеленим листям, формою крони. По-друге: розмішення їх у кварталі
№ 1 сприяє полегшенню догляду за насадженнями рододендронів, зокрема можливості вчасного поливу і зрошення рослин у спекотні дні сезону завдяки наявності водопровідної системи, натомість у новій та історичній частині парку полив виконується лише механізовано. Тому до уваги було прийнято існуючі на даній місџевості деревні насадження, наявні будови та водопровідна система поливу. Даний вибір грунтувався на біолого-екологічних особливостях росту і розвитку рододендронів, зокрема потреби рослин до таких екологічних факторів, як склад грунту, світло, волога та конкуренџія кореневих систем супутніх рослин. На жаль, ці питання не завжди було вирішено на користь рододендронів, зокрема врахування таких факторів, як освітлення і «сусідство» ділянок із зрілими деревами родів Picea L. і Aesculus L. - дерев з потужною поверхневою кореневою системою, шо проникає у шар субстрату з коренями рододендронів, чим негативно впливає на водний баланс рододендронів.

Створюючи в ландшафті адміністративної частини парку ділянки рододендронів, ми намагались врахувати рекомендаџії шодо вироџування рододендронів вітчизняних та зарубіжних фахівџів у џій галузі декоративного садівниџтва, зокрема щодо вибору місџя для їх висаджування, підготовки субстрату (Zarubenko, 2000; Zarubenkoet al., 2004; Tymchyshyn, 2003; Kondratovich, 1981; Radishchev, 1972; Botianovskii, 1981; Dostalkova, 1981), адже в умовах південної частини Правобережного Лiсостепу України, де розташований дендрологічний парк «Софіївка», культура рододендронів відкритого грунту є новою.

Так, у 1993-2004 роках на території адміністративної частини створено 11 куртин рододендронів

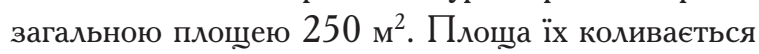
в межах 3-60 м². Кожну з них можна розглядати як самостійно, так і як складову експозиџійних ділянок, в яких рододендрони виступають домінантою. Приймаючи до уваги основні принџипи створення композиџійних картин на певному ландшафті (систематичний, екологічнй̈, декоративно-біологічний (фізіономічний), фітоџенотичний, архітектурний), пропоновані Кучерявим В. П. (Kucheriavyi, 2005), більшість ї були враховані при створенні насаджень рододендронів у дендрологічному парку «Софіївка» (Vehera, 2017; 2018).

Як було зазначено вище, у 1990-х роках формування насаджень на колекџійно-експозиџійних 
ділянках рододендронів у вигляді моногруп було розпочато саме за систематичним принџипом. У той період відбувалось стрімке збільшення колекшії представників роду Rhododendron і виникла необхідність розмістити її в експозиџійній частині кварталу № 1. Крім того, після дороџування сіянџів у шкілџі їх також частково висаджували в експозиџійних ділянках адміністративної зони та в прилеглому до неї кварталі. Використовуючи систематичний принџип, саджанџі рододендронів намагались розподіляти за таксономічними рангами (підродами та секціями згідно системи A. Rehder (Rehder, 1949). Такий ix розподіл допомагає орієнтуватись у роботі з великим різноманіттям роду. Розподіл видів роду дав можливість дотриматись гармонійного групування рододендронів за біологічними особливостями (декоративно-біологічний принџип), зокрема за періодом облиствлення, џвітіння тощо. Так утворились ділянки з ранньоквітучими напіввічнозеленими рододендронами, листопадними ранніх і середніх строків џвітіння, вічнозеленими середніх і пізніх строків џвітіння (рис. 1). 3 плином часу ділянки 1, 3, 9 почергово зазнавали реконструкџї (ділянку з вічнозеленими рододендронами розширили напіввічнозеленими і навпаки), у наслідок чого вони стали змішаними, однак џе не знизило їх декоративності. Біля ділянок 1 (2015 р.) і 6 (2018 р.) було видалено зрілі пошкоджені дерева і кущі (яблуня, ялина, калина бульденеж), унаслідок чого було порушено умови освітлення вічнозелених рододендронів на џих ділянках (екологічний принџип). Џе в свою чергу ускладнило підтримування водного балансу та призвело до частих опіків листків та випаду кущів деяких видів рододендронів.

Необхідно зауважити, шо створення ділянок для інтродуџентів роду Rhododendron в умовах дендрологічного парку «Софіївка» розпочиналось з повної заміни важкого за механічним складом грунту на субстрат з низинного, верхового торфу, прілої соснової хвої з домішками піску, перегною через невідповідність останнього для росту і розвитку рододендронів. Такий агротехнічний захід в умовах дендрологічного парку «Софіївка» $є$ необхідним як для росту Rhododendron, так і для всіх представників родини Ericaceae у џілому (екологічний принџип). Крім того, намагались враховувати умови освітлення ділянок і сусідство їх із близько розмішеними насадженнями з метою запобігання конкуренџї поверхнево розмішеної кореневої системи дерев з корінням кушів рододендронів.

Висновки/Conclusions. Отже, передумовою відновлення насаджень роду Rhododendron у Національному дендрологічному парку «Софіївка» $\epsilon$ використання представників даного роду в озелененні партерної частини парку у XVIII ст. за часів правління Потоџьких. У 1990 -х роках постало завдання відновлення інтродукџї Rhododendron у дендрологічному парку «Софіївка» на прикладі ботанічних садів України. Були враховані досвід та доробки фахівџів установ України та зарубіжжя, що дало можливість у наступні кілька десятиріч суттєво поповнити колекџію роду Rhododendron у Наџіональному дендрологічному парку «Софіівка». 3 метою збереження представників колекџї роду було прийнято рішення розмістити колекџійноекспозиџійні ділянки на території адміністративного кварталу. Такий вибір передбачав вирішення питання благоустрою і озеленення џієї частини парку розширеним асортиментом гарно квітучих кушів та полегшення догляду за насадженнями, зокрема можливості вчасного поливу і зрошення рослин у спекотні дні сезону. Створення ділянок та розмішення на них таксонів рододендронів грунтувалось на біолого-екологічних особливостях їх росту і розвитку, зокрема на потребі рослин у таких екологічних факторах, як склад грунту, світло, волога. Також було прийнято до уваги вплив кореневих систем супутніх рослин.

Наведено план-схему кварталу № 1 (Адміністративна ділянка парку) з розташуванням 11-ти колекџійно-експозиџійних ділянок Rhododendron та представлено на кожній з них таксономічний склад рослин. Побудована план-схема слугуватиме проведенню локального моніторингу ділянок та їх видового складу у даному кварталі. 


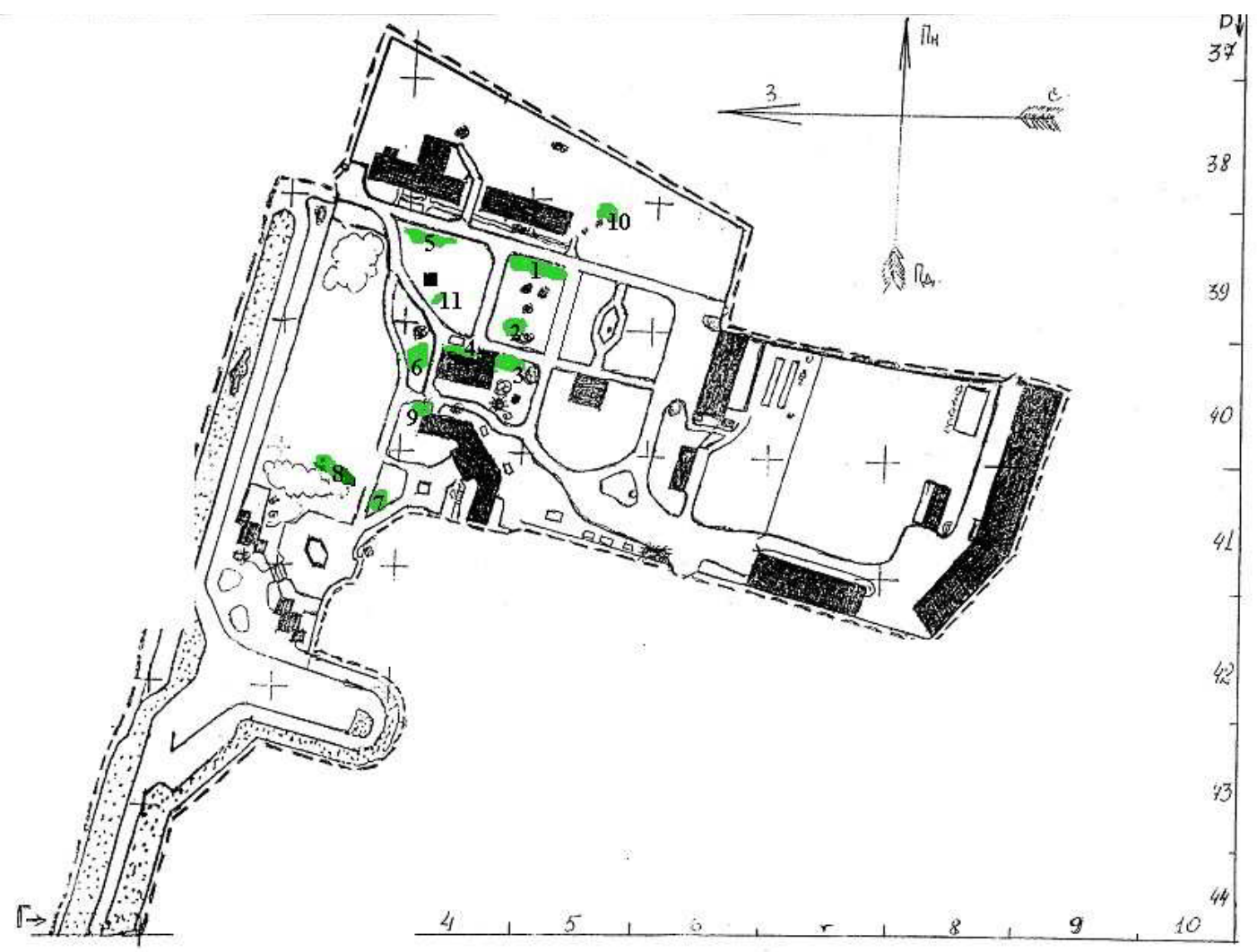

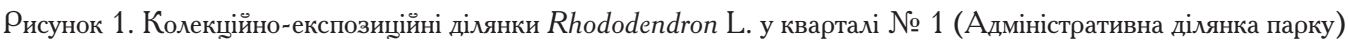
Figure 1. Collection and exposition plot of Rhododendron L. in Section 1 (administrative part of the park):

1 - Rh. ambiguum Hemsl., Rh. favevae, Rh. fauriei Franch., Rh. maximum L., Rh. smirnowii Trautv., Rh. sichotense Pojark., Rh. ledebouri Pojark., Rh. mucronulatum 'Pentoterum', Rh. galectinum Balf., Rh. fortunei Lindl., Rh. catawbiense var. hybridum, Rh. wilsonae Hemsl. et E. H. Wils., Rh. × stanvellianum Millais, Rh. argirofyllum Franch., Rh. concinnum Hemsl., Rh. cuneatum W.W. Smith, Rh. hyperythrum Hayata, Rh. yakusimanum Nakai, Rh. wilsonae Hemsl. et E. H. Wils.;

2 - Rh. fauriei Franch., Rh. makinoi Tagg, Rh. smirnowii Trautv., Rh. 'Baden-Baden', Rh. racemosum Franch., Rh. hybridum hort., Rh. cuneatum W. W. Smith, Rh. argirophyllum Franch., Rh. decorum Franch;

3 - Rh. schlippenbachii Maxim., Rh. calendulaceum Torr., Rh. occidentale (Torr. et A. Gray) A. Gray, Rh. japonicum (A. Gray) Suring., Rh. japonicum 'Aureum', Rh. canadense (L.) Torr., Rh. arborescens (Pursh) Torr., Rh. roseum (Loisel.) Rehd., Rh. obtusum 'Hinodegiri', Rh. obtusum (Lindl.) Planch., Rh. poukhanense Levl;

$4-R h . \times$ cunninghamii Moore, Rh. orbiculare Decne., Rh. fortunei Lindl., Rh. catawbiense Michx., Rh. 'Marouise de Brazais', Rh. yakusimanum Nakai;

5 - Rh. hybridum hort., Rh. ponticum L., Rh. micranthum Turcz., Rh. metternichii Sieb. et Zucc., Rh. brachycarpum D. Don ex G. Don, Rh. smirnowii Trautv., Rh. smirnowii × catawbiense, Rh. sichotense Pojark., Rh. 'Marina', Rh. mucronulatum 'Alba';

6 - Rh. Rh. 'Marouise de Brazais', Rh. racemosum Franch., Rh. 'Klonduke', Rh. roseum (Loisel.) Rehd., Rh. mucronulatum Turcz., Rh. sichotense Pojark., Rh. japonicum (A. Gray) Suring., Rh. nudiflorum (L.) Torr., Rh. luteum 'Glauca', Rh. maximum L., Rh. orbiculare Decne., Rh. dauricum 'Mucronulatum', Rh. hybridum hort.;

7 - Rh. ledebourii Pojark., Rh. sichotense Pojark., Rh. dauricum L.;

8 - Rh. sichotense Pojark., Rh. ledebourii Pojark.;

9 - Rh. oreodoxa Franch., Rh. yakusimanum Nakai, Rh. hybridum hort.,

10 - Rh. mucronulatum 'Pentoterum', Rh. sichotense Pojark.;

11 - Rh. sichotense Pojark. 


\section{Список посилань/References}

Aleksandrova, M. S. (2000). Aristokraty sada: krasivotsvetushchie kustarniki. M.: ZAO «Fiton». $192 \mathrm{s.}$ (in Russian).

Botianovskii, I. E. (1981). Kultura rododendronov v Belorussii. Minsk, 1981. 96 s. (in Russian).

Vanzar, O. M. (1998). Introduktsiia rododendroniv v Pivnichnij Bukovyni: avtoref. dys. na zdobuttia nauk. stup. kand. biol. nauk: spetsial'nist' 03.00.05 «Botanika». Kyiv. 17 s. (in Ukrainian).

Vegera, L. V. (1995). Istoriia introduktsii vidov Rhododendron L. v dendroparke «Sofievka» NAN Ukrainy. Zabytkowe ogrody oraz probleme ich ochrony: materiały z międzynarodowego sympozjum. Bolestraszyce. Leszyt 3. E. 113-114. (in Russian).

Vegera, L. V. (1995). Introduktsiia rododendrona Ledebura v dendroparke «Sofievka» AN Ukrainy. Introduktsiia i akklimatizatsiia rastenii. Kiev: Naukova dumka. Vyp. 23. S. 6-7. (in Russian).

Vehera, L. V. (2000). Bioekolohichni osoblyvosti ta kul'tura rododendroniv v umovakh Pravoberezhnoho Lisostepu Ukrainy: avtoref. dys. na zdobuttia nauk. stup. kand. biol. nauk: spets. 03.00 .05 «Botanika». Kyiv. 17 s. (in Ukrainian).

Vehera L. V. (2002). Osoblyvosti vprovadzhennia rododendroniv v umovakh Pravoberezhnoho Lisostepu Ukrainy. Botanicheskie sady: sostoianie i perspektivy sokhraneniia i izucheniia, ispolzovaniia biologicheskogo raznoobraziia rastitelnogo mira. Minsk. S. 37-38. (in Ukrainian).

Vehera, L. V. (2006). Bioekolohichni osoblyvosti ta kul'tura rododendroniv v umovakh Pravoberezhnoho Lisostepu Ukrainy. Uman': ALMI. 196 s. (in Ukrainian).

Vehera, L. V. (2011). Rododendrony Yevrazijs'kykh okhoronnykh spyskiv v kolektsii Natsional'noho dendroparku «Sofiivka». Naukovyj visnyk NLTU Ukrainy. L'viv: NLTU. Vyp. 21.10. S. 24-30. (in Ukrainian).

Vehera, L. V. (2017). Peredumovy stvorennia rododendronovykh sadiv v Ukraini. Aktual'ni problemy ozelenennia naselenykh mists': osvita, nauka, vyrobnytstvo, mystetstvo formuvannia landshaftu: tezy dopovidej III Mizhnarodnoi naukovo-praktychnoi konferentsii. Bila Tserkva. S. 166-167. (in Ukrainian).

Vehera, L. V. (2017). Osoblyvosti stvorennia sadu rododendroniv v dendroparku «Sofiivka» NAN Ukrainy. Aktual'ni pytannia sadovo-parkovoho hospodarstva: materialy naukovo-praktychnoi Internet-konferentsii (m. Uman', 6 chervnia 2017 r.). Uman'. S. 65-68. (in Ukrainian).

Vehera, L. V., Mazurenko, V. D. (2018). Stvorennia stijkykh fitotsenoziv rododendronovykh sadiv v umovakh Ukrainy: peredumovy ta pidkhody. Naukovyj visnyk NLTU Ukrainy. T. 28. № 6. S. 14-17. (in Ukrainian). DOI https://doi. org/10.15421/40280602

Kolisnichenko, O. M., Boniuk, Z. H., Hrevtsova, H. T., Zarubenko, A. U., Ivanova, I. Yu., (2003). Derevni roslyny botanichnoho sadu im. akad. O.V. Fomina Kyivs'koho natsional'noho universytetu im. Tarasa Shevchenka. Kyiv: Fitosotsiotsentr. 84 s. (in Ukrainian).

Zarubenko, A. U. (1989). Introduktsiia rododendronov. Okhrana, izuchenie i obogashchenie rastitelnogo mira. Kiev: Izdatelstvo pri Kievskom gosudarstvennom universitete. Vyp. 16. S. 16-20. (in Russian).

Zarubenko, A. U., Tymchyshyn, H. V., Shumyk, M. I. (2004). Metodychni rekomendatsii z rozmnozhennia ta kul'tyvuvannia rododendroniv v Ukraini. - Kyiv: Fitosotsiotsentr. 31 s. (in Ukrainian).

Zarubenko, A. U. (2001). Rododendrony dlia dekoratyvnoho sadivnytstva (lystopadni ta napivvichnozeleni vydy). Zhurnal «Kvity Ukrainy». № 9.50 s. (in Ukrainian).

Zarubenko, A. U. (1996). De ta iak sadzhaty rododendrony. Zhurnal «Kvity Ukrainy». № 2. S. 14-15. (in Ukrainian).

Zarubenko, A. U. (2000). Vykorystannia gruntovykh substrativ ta orhanichnykh dobryv dlia vyroschuvannia sadzhantsiv rododendroniv. Visnyk Kyivs'koho universytetu. Biolohiia. Vyp. 30. S. 22-25. (in Ukrainian).

Zarubenko, A. U. (2006). Kultura rododendroniv v Ukraini. Kyiv: Vydavnycho-polihrafichnyi tsentr «Kyivskyi universytet». $175 \mathrm{~s}$. [in Ukrainian].

Kosenko, I. S., Khraban, H. Yu., Harbuz, V. F. (1996). Dendrolohichnyj park «Sofivka». 200 rokiv. Kyiv: Naukova dumka. 191 s. (in Ukrainian).

Kondratovich, R. Ia. (1981). Rododendrony v Latviiskoi SSR. Biologicheskie osobennosti kultury. Riga: Zinatne. 332 s. (in Russian). 
Kucheriavyi V.P. (2005). Ozelenennia naselenykh mists. Lviv: Svit. 456 s. [in Ukrainian].

Radishchev, A. P. (1972). Rododendrony v sadovoi kulture. Moskva: Izd-vo Moskovskogo universiteta. $68 \mathrm{~s}$. (in Russian).

Tymchyshyn, H. V. (2003). Biolohiia ta osoblyvosti kul'tury rododendroniv (Rhododendron L.) na Zakhidnomu Podilli: avtoref. dys. na zdobuttia nauk. stup. kand. biol. nauk: spetsial'nist'. 03.00.05 «Botanika». Kyiv. 17 s. (in Ukrainian).

Tymchyshyn, H. V. (2003). Rododendrony ta ikh vyroschuvannia (praktychni rekomendatsii). Kyiv. 16 s. (in Ukrainian).

Shumyk, M. I. (2012). Landshaftno-ekolohichnyj pryntsyp stvorennia ekspozytsijnoi kolektsii roslyn rodyny Ericaceae Juss. ex situ. Visti biosfernoho zapovidnyka «Askaniia - Nova»: naukovyj zhurnal. № 14. C. 413-418. (in Ukrainian).

Dostalkova, A. (1981). Rhododendrony. Praga.157 s.

Rehder, A. (1949). Manual of cultivated trees and shrubs. New York: The Macmillan company. 996 p.

УДК 581.6

\section{Декоративні властивості представників роду Hydrangea L. у Правобережному Лісостепу України}

Альона В. Гончарова

Наџіональний дендрологічний парк «Софіївка» НАН України, Черкаська обл., Україна, e-mail: ukrcargo@ukr.net ORCID ID0000-0001-6218-4691

\section{Реферат.}

Mema. Рід Hydrangea L. належить до родини Гортензієві (Hydrangeaceae Dumort.), яка об’єднує 19 родів і 260 видів деревних та оранжерейних рослин, поширених в помірній і субтропічній зонах Північної півкулі, головним чином у Північній Америџі та Східній Азії (Китай, Японія). Рослини роду Hydrangeа широко використовують в зеленому будівниџтві, проте їхі декоративні властивості є недостатньо дослідженими. Тому мета нашої роботи полягала у визначенні декоративних властивостей представників роду Hydrangea за інтродукџї у Правобережному Лісостепу України. Методи. В умовах НДП «Софіївка» обстежено насадження представників роду Hydrangea. За методикою Н. В. Котелової та О. Н Виноградової в модифікаџї І. В. Таран, А. М. Агапової оџінювали декоративність рослин досліджуваних видів, зокрема квіток, пагонів, листків та загальну декоративність

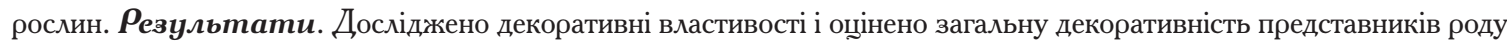
Hydrangea. Визначено перспективи їх використання в озелененні та створенні ландшафтних композиџій. Завдяки довготривалому џвітінню та зміні забарвлення листків і суџвіть впродовж вегетаџії, можливе також використання ïx у вертикальному озелененні та для декораџії берегів водойм, зміџнення схилів, а також як грунтопокривних рослин під кронами дерев. Наведено характеристику декоративних властивостей представників роду Hydrangea в дендрологічному парку «Софіївка» НАН України.

Ключові слова: Hydrangeaceае, декоративність, џвітіння, ландшафтні композиџії. 